\title{
川崎病における治療反応性とバイオマーカー
}

阿部淳，松田明生

\section{Biomarkers associated with unresponsiveness to IVIG in children with Kawasaki disease}

\author{
Jun ABE and Akio MATSUDA \\ Department of Allergy and Immunology, National Research Institute for Child Health and Development
}

(Accepted December 13, 2012)

\begin{abstract}
summary
We have adopted DNA-microarray technology to analyze gene expression profiles in patients with Kawasaki Disease (KD). The results demonstrated that neutrophils in acute KD patients were not only expanded in number but also activated through the expression of a variety of late-stage granulocyte-specific genes such as polycythemia rubra vera 1 (PRV-1) and haptoglobin compared with febrile controls. In accordance with these findings, serum granulocyte colony-stimulating factor (G-CSF) levels were also higher in IVIG-resistant patients than those in responsive patients. These results might indicate evidences for dysregulated immunological pathways in KD patients and provide possible tools for diagnosis and prognostics of KD. We also found that high-dose IgG specifically and completely inhibited accelerated expression of KD-related cytokines such as G-CSF, IL- 6 and IL- $1 \beta$ by HCAEC in response to TNF- $\alpha$. The suppression of these cytokine genes correlated closely with functional inhibition of a transcription factor, C/EBP- $\delta$. These findings suggest that the clinical effects of IVIG on KD patients are at least in part due to its direct anti-inflammatory effects on the coronary endothelium, which is a major lesion site in the pathogenesis of KD.
\end{abstract}

Key words_ $\quad$ Kawasaki disease; Biomarker; Immunoglobulin; IVIG; PRV-1

抄録

川崎病に拈ける IVIG 療法の効果について，その詳細な機序は未だ不明な点が多い。初回 IVIG 療法に不応の患 者も 20〜30\%いるので，冠動脈瘤の発症を予防するためには早期に治療反応性を予測する必要がある。私共は， DNA マイクロアレイを用いた遺伝子発現プロファイリングの結果から，川崎病急性期には好中球数が増加するの みならず, polycythemia rubra vera 1 など顆粒球の分化段階に特異的な遺伝子を発現して質的にも異なることを明 らかにした。これに対応して血清中の G-CSF 濃度も，IVIG 不応群では反応良好群に比べて有意に高く，これら の因子が治療反応性の予測マーカーになると考えられた。さらに，IVIG 療法で用いられる濃度の IgG が TNF- $\alpha$ 刺激を受けたヒト冠動脈血管内皮細胞に直接作用して，G-CSF や IL-6 などのサイトカイン産生発現を強く抑制す ることを明らかにした。この IgGの抗炎症作用は，これらのサイトカインの転写活性化因子である C/EBP- $\delta$ の産 生抑制と並行してみられることから，血管内皮細胞における炎症反応増幅機構の抑制に関与している可能性が示唆 された。

\section{はじめに}

川崎病は，乳幼児に好発する原因不明の血管炎で ある. 国内の発症数は年々増加傾向にあり年間 1 万 例を超えている1). 1967 年に川崎富作博士により初 めて報告されたが，今日まで病因が明らかにされて いないために特異的な診断法や治療法がなく, 病因 の解明が喫緊の課題となっている，また，全患者の 約 4\%に発生する冠動脈瘤の発症を予防するために

国立成育医療研究センター研究所免疫アレルギー研究部
は，できるだけ発症早期に炎症を抑え込むことが有 効とされている. 免疫グロブリン大量静注（IVIG） 療法が川崎病の標準治療だが，確定診断のためには 症状が出揃うのを待たねばならない中で，できるだ け早期に IVIG 療法を開始して心後遺症の発生リス クを最小にしなければならないジレンマをどう解決 するかが，川崎病の診断で直面する問題である。さ

らに，IVIG 療法を受けた患者の 20〜30\%が初回投 与では解熱しないため, 追加の IVIG 療法やプレド ニゾロン, メチルプレドニゾロンパルス，抗 TNF$\alpha$ 抗体製剂のインフリキシマブやシクロスポリン, 
血漿交換などのより強力な治療を必要とする。この ような患者を早期に判別して，より有効な急性期治 療を行うための科学的エビデンスを確立することが 治療面での課題である. 本稿では, これらの諸問題 のなかで，とくに IVIG 療法への反応性を予測する バイオマーカーについて, 私共の研究室での経験を 中心に概説する.

\section{I. 川崎病治療の課題}

川崎病は特定の臨床症状の組合せで診断される. 日本では, 2002 年に改定された「川崎病診断の手 引き（厚生労働省川崎病研究班作成，表 1)」に基 づいて, 主要症状とされる 6 症状のうち 5 症状が揃 った時点で確定診断される（確実 $\mathrm{A})^{2}$. .さらに， 冠動脈瘤が認められる場合には 4 症状でも川崎病と 診断してよい（確実 B)。しかし，これらの主要症 状が同時に出現しない患者も多く，また一方では症 状数が足りないけれども他の疾患が否定され，川崎 病と診断せざるを得ない患者も存在する ${ }^{3)}$. このよ うな患者は不全型川崎病とされ，全患者の約 15～ $20 \%$ に相当する. 6 ヶ月未満の乳児や 4 歳以上の年 長児に多く，冠動脈障害の好発年齢々も重なるの で，川崎病の心後遺症の予防をすす女る上での障碍 となっている.

不全型川崎病とともに今, 川崎病の心後遺症の予 防をすすめる上で問題となっているのは，初回の IVIG 療法後も解熱の得られない，いわゆる免疫グ ロブリン不応例の存在である。 日本川崎病学会の用 語委員会によれば，免疫グロブリン不応例は「通常
総量 $2 \mathrm{~g} / \mathrm{kg}$ の IVIG 投与終了後 24 時間以上持続す る発熱, または 24 時間以内に再発熱が認められた 場合とする」と定義される4). 投与後に解熱が得ら れるか否かが判定基準であり，米国循環器学会 （AHA）の川崎病治療診断指針でも，投与終了後 36 時間々観察期間は異なるが同様の判定基準を用 いている5 .しかし実際には，微妙な境界領域の発 熱が持続したり，24 時間以降に再発熱が出現した りして治療効果の判断が難しい症例も多い，そのた め日本の用語委員会の定義にも，「判定には発熱以 外の急性期症状や検査結果の改善度も勘案する.」 という一文が加えられている．追加治療のタイミン グと基準をどうするか，その決定は現場の小児科医 の判断に委ねられているのが現状である.

次に，初回 IVIG 不応例に対する追加治療の内容 はどのようなものだろうか. 2011 年の第 21 回全国 調査によれば，IVIG の追加投与が 91.5\%を占めて 圧倒的に多いが，「川崎病急性期治療のガイドライ ン（日本小児循環器学会, 2003）」では, IVIG 療 法以外の治療手段として経ロステロイド，メチルプ レドニゾロンパルス, 好中球エラスターゼ阻害薬, 血漿交換などの追加治療を紹介している（表 2 $)^{6}$. しかし近年，生物学的製剤であるインフリキシマブ やシクロスポリンなどによる新規治療法も IVIG 不 応の川崎病患者の治療に比較的広く用いられるよう になってきている．最近の IVIG 不応例に対する追 加治療がどのように変遷しているのか，その概略は 隔年で実施されている川崎病全国調査成績の報告か ら知ることができるので，興味のある方は参照して

表 1 川崎病診断の手引き（厚生労働省川崎病研究班作成改訂 5 版 2002 年）

本症は，主として 4 歳以下の乳幼児に好発する原因不明の疾患で，その症候は以下の主要症状と参考条項とに分けられる。
A 主要症状
1. 5 日以上続く発熱（ただし，治療により 5 日未満で解熱した場合も含む)
2. 両側眼球結膜の充血
3. 口唇, 口腔所見 : 口唇の紅潮, いちご舌, 口腔咽頭粘膜のびまん性発赤
4. 不定形発疹
5. 四肢末端の変化：(急性期）手足の硬性浮腫，掌蹠ないしは指趾先端の紅斑
（回復期）指先からの膜様落屑
6. 急性期に抢ける非化膿性頸部リンパ節腫脹

\footnotetext{
6つの主要症状のうち 5 つ以上の症状を伴うものを本症とする．ただし，上記 6 主要症状のうち，4つの症状しか認められな くても，経過中に断層心エコ一法もしくは，心血管造影法で，冠動脈瘤（いわゆる拡大を含む）が確認され，他の疾患が除外 されれば本症とする.
} 
表 2 IVIG 療法以外の治療手段

\begin{tabular}{|c|c|c|}
\hline 治療法 & 投与法 & 副作用と注意点 \\
\hline $\begin{array}{l}\text { 経ロステロイド } \\
\text { (プレドニゾロン) }\end{array}$ & $\begin{array}{l}2 \mathrm{mg} / \mathrm{kg} / \text { 日内服 } 2 \text { 週間 } \\
\text { 以後 } 6 \text { 週間か子漸減中止 }\end{array}$ & $\begin{array}{l}\text { 漸減時再燃あり．巨大動脈瘤とその破裂が高く } \\
\text { なる厽険性あり }\end{array}$ \\
\hline $\begin{array}{l}\text { ステロイドパルス } \\
\text { (メチルプレドニゾロン) }\end{array}$ & $\begin{array}{l}30 \mathrm{mg} / \mathrm{kg} / \text { 日 } \\
\text { 点滴静注 } 1 \sim 3 \text { 日間 }\end{array}$ & 高血圧，血栓症，電解質異常 \\
\hline $\begin{array}{l}\text { 好中球エラスターゼ阻害剤 } \\
\text { (ウリナスタチン) }\end{array}$ & $\begin{array}{l}\text { ミラクリッドとして } 5,000 \text { 単位 } / \mathrm{kg} \_3 \sim 6 \text { 回/日 } \\
\text { 点滴静注数日間 }\end{array}$ & 自血球減少 \\
\hline $\begin{array}{l}\text { 血漿交換 } \\
(5 \% \text { アルブミン液) }\end{array}$ & $\begin{array}{l}\text { 循環血䊢量と同 } \\
1 \text { 1 } 3 \text { 間 }\end{array}$ & ショック, 血管損傷 \\
\hline
\end{tabular}

いただきたい1)。「川崎病急性期治療のガイドライ ン」も近々に改訂される予定だが，有効な治療法を 決定するためにはランダム化比較試験を含む大規模 な臨床研究が必要であろう。

\section{II. 免疫グロブリン不応例の予測}

川崎病に対して IVIG 療法が広く用いられ始めた 頃，その適応を決定するための方法として原田スコ アが提唱された（表 3$)^{7)}$. 末梢血液検査の白血球数 や血小板数，ヘマトクリット值など 7 つ項目を基 準化して，4 項目以上が陽性となった症例に IVIG 療法を推奨するというものである. その後, 免疫グ ロブリン不応例を予測する場合にも血液検査や患者 の年齢や発症後の日数などの臨床データが活用でき ないか，種々の試みがなされてきた，最近では，群 馬スコア, 久留米スコア, 大阪スコア, などが相次 いで提唱され，それぞれ良好な感度と特異度で IVIG 不応例を予測することができると報告され た ${ }^{8 \sim 10)}$. 群馬スコアは患者の月歯, 発症後の日数, 好中球 $\%$, 血小板数, 血清 $\mathrm{Na}$ 值, AST 值, CRP 值の 7 項目, 久留米スコアは患者の月齢, 発症後の 日数, 血小板数, 血清 AST 值, CRP 值の 5 項目, 大阪スコアは血清 AST 值, CRP 值, 総ビリルビン 值の 3 項目で計算式を作り, 総得点で判定するシス テムである. Kobayashi らはその後, 群馬スコアを 用いて未治療の川崎病患者を層別化し，スコアの高 いハイリスクな患者だけを対象として IVIG 単独療 法と IVIG＋ステロイドの併用療法を比べる大規模 なランダム化比較試験（RAISE Study）を行い，ス テロイド併用療法の優位性を証明した ${ }^{11)}$. Ogata ら も，同様に久留米スコアを用いて患者を層別化し， メチルプレドニゾロンパルスの初期併用療法の優位 性を証明している12)。これらの論文により，免疫グ ロブリン不応例の予測が臨床研究にも有益であるこ とが示されたわけだが，これらのスコア・システム
表 3 原田のスコア

\begin{tabular}{|c|c|}
\hline 1. 白血球数 & $12000 / \mathrm{ul}$ 以上 \\
\hline 2. 血小板数 & 35 万/ul 未満 \\
\hline 3. CRP & $4.5 \mathrm{mg} / \mathrm{dl}$ 以上 \\
\hline 4. ヘマトクリット值 & 35\%未満 \\
\hline 5. 血清アルブミン值 & $3.5 \mathrm{~g} / \mathrm{dl}$ 未満 \\
\hline 6. 年齢 & 12 ケ月以下 \\
\hline 7. 男児 & \\
\hline
\end{tabular}

急性期に上記 7 項目中 4 項目以上を満たした場合に $\gamma$-グロブリンを投 与する.

第 9 病日までの最も不良な值で判定する.

が人種差をこえて世界で汎用できるかについては, 米国の研究グループからは疑問視する報告も出され ている13). とくに発症後の日数をスコアに数える方 法は，各国の医療情勢の影響を受けるだけに，より 精度の高い客観的なバイオマーカーの開発が待たれ ているのが現状である.

\section{III. マイクロアレイ解析から得られた バイオマーカー}

私共の研究室では, 川崎病の病態を包括的に理解 することを目的として急性期患者の遺伝子発現プロ ファイルを, PAXgene $\mathrm{TM}^{\mathrm{MM}}$ システムと DNA マイク ロアレイを用いて解析している14,15)。その中で, IVIG 療法によって患者の末梢血中の免疫細胞がぞ のような影響を受けるかを, IVIG 療法前, IVIG 療法後, 発熱対照の 3 群の患者を対象として調べ た。 その結果, IVIG 療法前の患者で発熱対照患者 と比べて有意に高く発現し，かつ IVIG 療法後に発 現が強く抑制された遺伝子プローブ 298 個を同定し た（図 1)。これら 298 個の遺伝子プローブを使っ て, 初回 IVIG 療法への反応良好群と不応群の治療 前後での遺伝子発現プロファイルを観察した（図 2). 治療前に発現の方進していた多くの遺伝子（図 2 の赤色のタイル）は, IVIG 療法後に, 反応良好 


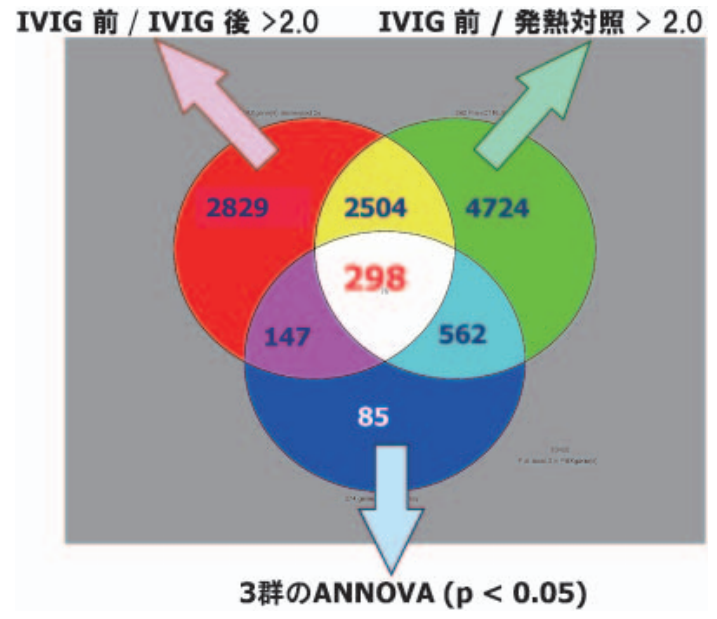

図 1 IVIG 療法後に発現が抑制された遺伝子

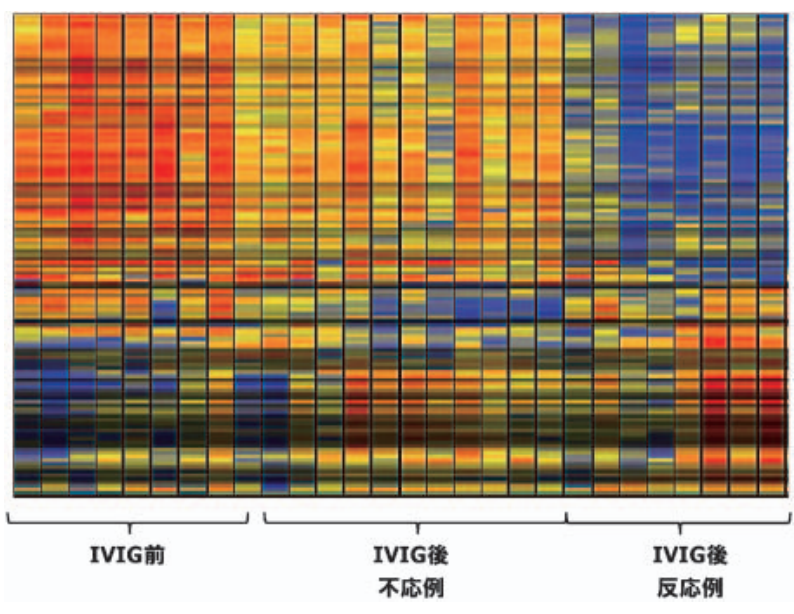

図 2 IVIG 反応例 · 不応例の遺伝子発現プロファイル

表 4 IVIG 不応例で発現が高かった遺伝子

\begin{tabular}{|c|c|c|c|}
\hline 遺伝子略号 & 不応例/反応例 & プローブ ID & 遺伝子名 \\
\hline HP & 4.44 & 208470_s_at & haptoglobin \\
\hline - & 2.21 & 239701_at & Transcribed sequence \\
\hline CD177 & 2.08 & 219669_at & Polycythemia Rubra Vera 1 \\
\hline SORT1 & 1.96 & 224818_at & sortilin 1 \\
\hline - & 1.87 & 225499_at & Clone CDABP0105 \\
\hline C20orf74 & 1.66 & 232500_at & chromosome 20 open reading frame 74 \\
\hline RBPJ & 1.66 & 211974_x_at & recombination signal binding protein for immunoglobulin kappa $\mathrm{J}$ region \\
\hline GAS7 & 1.59 & 202191_s_at & growth arrest-specific 7 \\
\hline ITGAM & 1.47 & 205786_s_at & integrin, alpha $\mathrm{M}$ (complement component 3 receptor 3 subunit) \\
\hline $\mathrm{SSH} 2$ & 1.42 & 226080_at & slingshot homolog 2 \\
\hline LOC150166 & 1.26 & 229295_at & hypothetical protein LOC150166 \\
\hline CENTD2 & 0.75 & 212516_at & centaurin, delta 2 \\
\hline SOD2 & 0.70 & 216841_s_at & superoxide dismutase 2 \\
\hline C6orf190 & 0.51 & 1558972_s_at & chromosome 6 open reading frame 190 \\
\hline LOC283666 & 0.42 & 226682_at & hypothetical protein LOC283666 \\
\hline
\end{tabular}

群では発現がほとんど無くなっていた（青色のタイ ル）のに対し，IVIG 不応群では発現が持続してい るものの治療前と比べると発現量は中くらい（黄色 のタイル）になっていることが分かった。すなわ ち, 免疫グロブリン不応例とされる患者でも IVIG 療法に対する反応が全く見られないわけではなく, ただその抑制効果が不十分なために不応という形を とるのではないかと考えられた3). どのくらい不十 分なのか，その程度には個体差があり，一定のスぺ クトルが存在するらしいことは図 2 の遺伝子発現プ ロファイルからも推察される. 追加治療として IVIG を投与した場合に, 初回 IVIG 投与後と同じ
く約 70〜80\%の患者が反応して解熱することも， マイクロアレイ解析の結果と合わせて，免疫グロブ リン不応例の「不応」が絶対的なものではないこと を示す所見であると思われる。

さらに興味深かったのは，これら298 個の遺伝子 プローブの中に顆粒球系細胞が骨髄で分化する途上 で特異的に発現する遺伝子が多く含まれていたこと である. 298 個のうち 107 個 (48\%) のプローブが, 骨髄球あるいは桿状核球の分化過程で多く発現する 遺伝子だった ${ }^{15,16)}$. IVIG 療法前の発現が反応良好 例と比べて不応例に沶いて最も高かった上位 15 個 のプローブを表 4 に示す．これらの遺伝子プローブ 


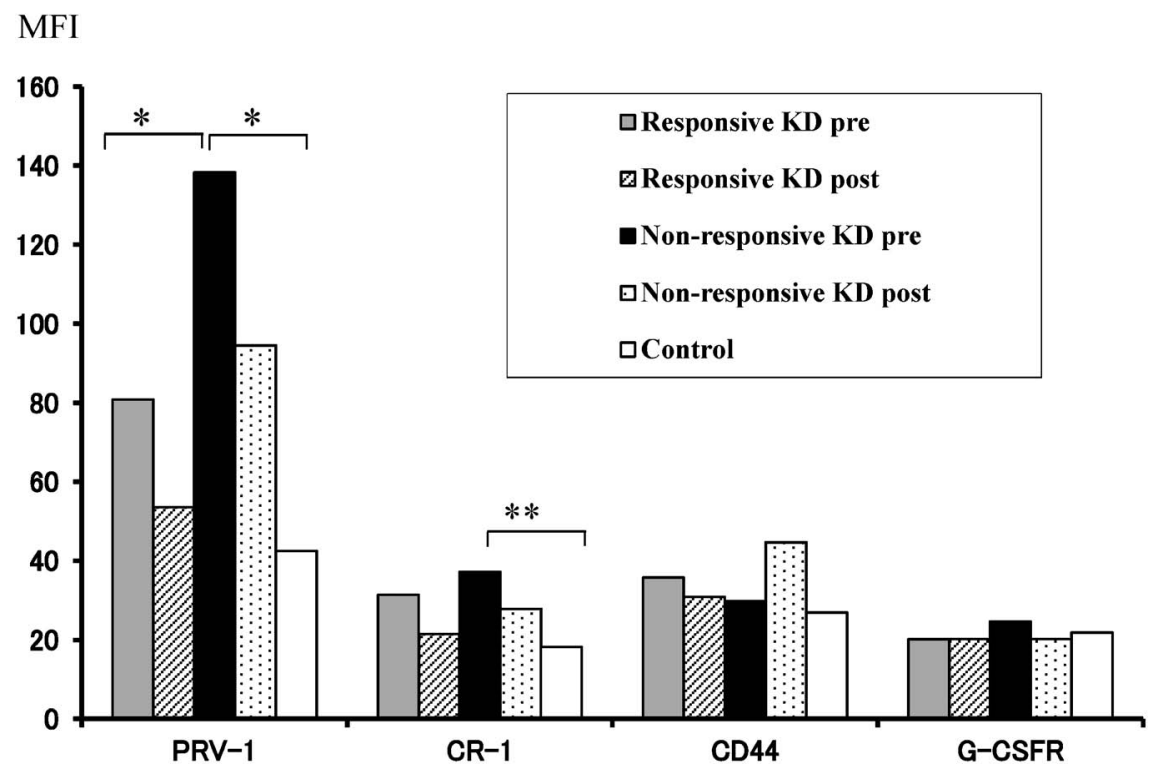

図 3 IVIG 反応群, 不応群に抢ける PRV-1 の発現量 $* \mathrm{P}=.001 * * \mathrm{P}=.0 .01$

の中から, 私共は IVIG 療法の前後で最も発現が大 きく変動する遺伝子として, polycythemia rubra vera $1(\mathrm{PRV}-1)$ という真性多血症患者の診断マー カーとしてクローニングされた遺伝子に注目した.

PRV-1 は, 骨髄で分化段階にある顆粒球に発現す るが，健常人の末梢血中の好中球では殆ど発現され ない細胞表面抗原であり，CD177 という白血球分 化抗原番号が付与されている ${ }^{17)}$. 真性多血症患者以 外では重症細菌感染症や G-CSF を投与された患者 の好中球の細胞表面に発現することが知られてい る18). 実際に, 川崎病患者の末梢血中の好中球での PRV-1 の発現をリアルタイム PCR および蛍光フ ローサイトメトリーで調べたところ， mRNA 抽よ び蛋白の発現量は治療前の川崎病患者では発熱対照 患者と比べて有意に高く, IVIG 反応良好例よりも 不応例に打いて有意に高值だった（図 3).さらに， 末梢血中に PRV-1 陽性の顆粒球を誘導する増殖因 子である G-CSF の血中レベルも，治療反応良好例 と比べて不応例に抢いて有意に高く, 血中の $\mathrm{G}-$ CSF 濃度と好中球の PRV-1 発現量には強い正の相 関があることも分かった ${ }^{15)}$ 。これらの結果から，

PRV-1 と G-CSF は, 川崎病の特徵である高サイ トカイン血症に連動して疾患の重症度を反映するバ イオマーカーとなる可能性が考えられた. 現在私共 は, この 2 つマーカーと各種の炎症性サイトカイ ンの測定值を組久合わせて IVIG 不応や冠動脈瘤発 症のリスクを予測する研究に取り組んでいる.

\section{IV. ヒト血管内皮細胞に対する免疫グロブリンの 作用}

PRV-1 と G-CSF はどうして川崎病の病態を 反映するバイオマーカーになるのだろうか．GCSF はマクロファージや血管内皮細胞, 血管平滑 筋細胞等から産生される造血系の増殖因子である.

TNF- $\alpha$ や IL-6 などの炎症性サイトカイン刺激でそ の産生は立進し，重症細菌感染症などの緊急時には 造血系幹細胞や桿状核球を骨髄から末梢へ動員する 作用をもつ ${ }^{19,20)}$ 。私共は, 川崎病急性期にみられる 血中 $\mathrm{G}-\mathrm{CSF}$ 濃度の上昇は, 炎症性サイトカインに よって血管内皮細胞からの G-CSF 産生が充進する ためではないかと推測した、そして，ヒト冠状動脈 血管内皮細胞（HCAEC）の培養系を使って，炎症 性サイトカインや IgG が血管内皮細胞に及ぼす影 響について調べることにした ${ }^{21)}$.

先ず，HCAEC を TNF- $\alpha$ で刺激培養してどのよ うな遺伝子の発現が充進するか, さらに高濃度 IgG を添加するとどのような遺伝子の発現立進が抑制さ れるかをDNA マイクロアレイで調べた．その結果，

G-CSF，IL-1 $\beta, I L-6$ など川崎病の急性期に上昇す る炎症性サイトカインが上位 10 位にリストアップ された（表 5)。これらのサイトカインの発現量の 時間的推移をリアルタイム PCR で調べたところ， $\mathrm{TNF}-\alpha$ の添加 12 時間後から 48 時間後までの間に G-CSF, IL-6 抢よび IL- $1 \beta$ の mRNA 発現量は徐 
表 5 高濃度 IgG で発現が抑制された遺伝子（HCAEC）

\begin{tabular}{lcll}
\hline \hline \multicolumn{1}{c}{ 遺伝子略号 } & TNF/TNF + IgG & \multicolumn{1}{c}{ プローブ ID } & \multicolumn{1}{c}{ 遺伝子名 } \\
\hline CSF3/G-CSF & 27.1 & 207442_at & colony stimulating factor 3 (granulocyte) \\
IL1B & 11.4 & 205067_at & interleukin 1, beta \\
CCL8 & 11.2 & 214038_at & chemokine (C-C motif) ligand 8 \\
IL6 & 9.6 & 205207_at & Interleukin 6 (interferon, beta2) \\
IL1B & 9.0 & 39402_at & interleukin 1, beta \\
TNFAIP6 & 8.2 & 206026_s_at & tumor necrosis factor, alpha-induced protein 6 \\
TNFAIP6 & 7.4 & 206025_s_at & tumor necrosis factor, alpha-induced protein 6 \\
C3 & 7.0 & 217767_at & complement component 3 \\
ITGB8 & 6.2 & 226189_at & Integrin, beta 8 \\
C15orf48 & 5.7 & 223484_at & chromosome 15 open reading frame 48 \\
\hline
\end{tabular}
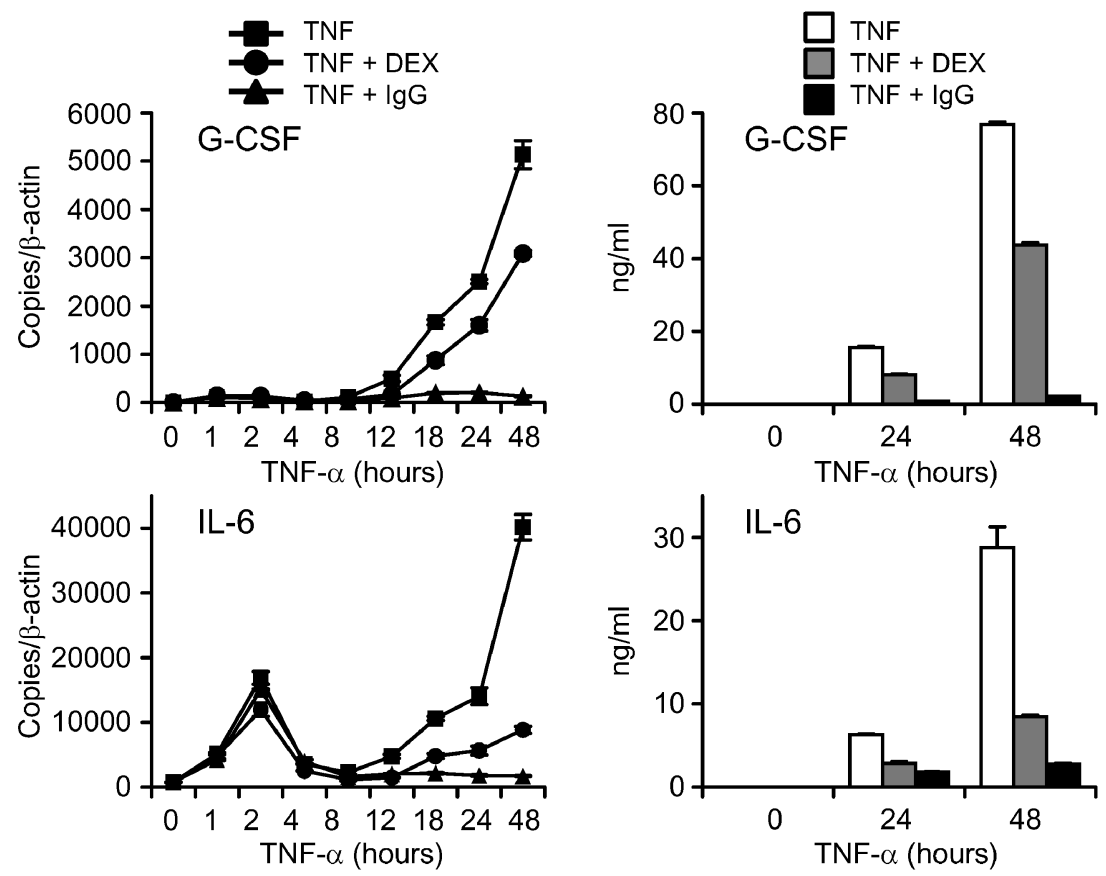

図 $4 \mathrm{TNF}-\mathrm{a}$ によるサイトカイン産生誘導と IgG による抑制

々に増加した。 IgG $(20 \mathrm{mg} / \mathrm{ml})$ はこれらの発現を ほぼ完全に抑制したのに対して，ステロイド（100 $\mathrm{nM}$ デキサメサゾン；DEX）は部分的に抑制しただ けだった。ささらに, HCAEC 培養上清中の $\mathrm{G}-\mathrm{CSF}$ および IL-6の濃度は上昇していたが，これらは $\mathrm{IgG}$ 添加によりほぼ完全に抑制された（図 4). 次 に, IgG 添加により $\mathrm{TNF}-\alpha$ からの刺激伝達シグナ ルにどのような影響が出るのか検討した． TNF- $\alpha$ の刺激伝達経路としては $\mathrm{NF}-\kappa \mathrm{B}$ 抢よび $\mathrm{MAP}$ キ ナーゼがよく知られている22,23). TNF-a 刺激後,

HCAEC 細胞質中の $\mathrm{NF}-\kappa \mathrm{B}$, Erk および $\mathrm{p} 38 \mathrm{MAPK}$ は速やかにリン酸化されたが， IgGを添加してもこ
れらのリン酸化は全く抑制されなかった。さらにゲ ルシフトアッセイで見ても, $\mathrm{NF}-\kappa \mathrm{B}$ p 65 の核内移 行と DNA への結合は, IgG を添加しても抑制され なかった。

さて，C/EBP ファミリー蛋白は，モノサイトや 顆粒球に打いて転写活性化複合体を作り, G-CSF および IL-6 の mRNA 産生を充進させることが知 られている24). 先のマイクロアレイの実験から, $\mathrm{TNF}-\alpha$ 刺激後の HCAEC では $\mathrm{C} / \mathrm{EBP}-\delta$ 遺伝子が 強く発現誘導されること, IgGの添加により発現が 抑制されることが分かった．実際に，リアルタイム PCR 打よびウェスタンブロットによる実験でも， 


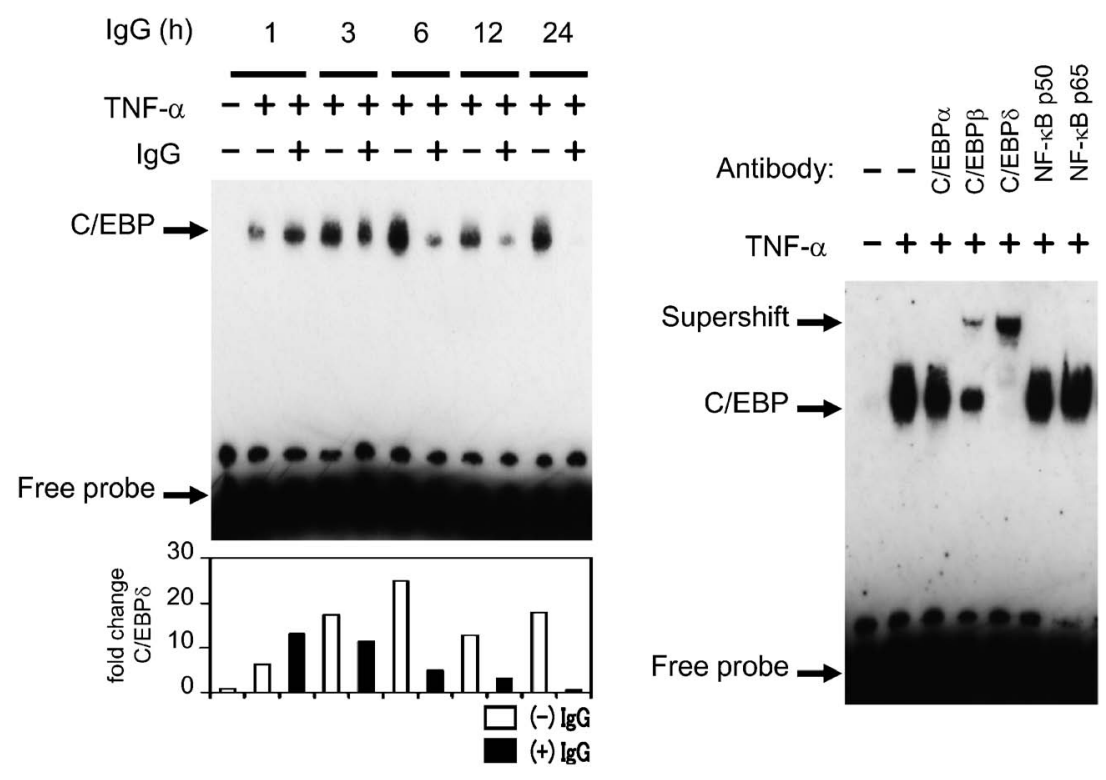

図 $5 \mathrm{TNF}-\mathrm{a}$ によるサイトカイン産生誘導と $\mathrm{IgG}$ による抑制

$\mathrm{C} / \mathrm{EBP}-\delta$ の発現量の変化は，図 4 の $\mathrm{G}-\mathrm{CSF}$ およ びIL-6の変動パターンときわめて良く一致した. さらにゲルシフトアッセイからも TNF- $\alpha$ で刺激し た HCAECの核内には DNA 結合能をもつC/ $\mathrm{EBP}-\delta$ が増加することが確認された（図 5). 以上 より, 高濃度 IgG は HCAEC に直接作用して, $\mathrm{TNF}-\alpha$ 刺激による $\mathrm{G}-\mathrm{CSF}$ や IL-6 の産生六進を抑 制すること，この作用には $\mathrm{NF}-\kappa \mathrm{B}$ や MAPK など のシグナル分子の一過性の活性化ではなく, 転写因 子 $\mathrm{C} / \mathrm{EBP}-\delta$ を始めとする何らかの増幅サイクルを 抑制することが機序として考えられることが明らか になった。

\section{おわりに}

川崎病患者の IVIG 反応性を予測するシンプルな バイオマーカーは，はたして見い出せるのだろうか. DNA マイクロアレイ解析を用いてこれまでいろい ろ試してきたが，単一で十分な働きをするマーカー は見つからなかった。 川崎病自体がシンプルな疾患 単位ではなくへテロな病態であることが原因なのか もしれない，そんな中で，同じく DNA マイクロア レイ解析から，急性期に増加する好中球が量的に増 えているのみならず，PRV-1 や haptoglobin など を発現して質的にも異なった好中球であることが分 かった点は興味深い。これは，抔そらく炎症性サイ トカインの刺激で末梢の血管内皮細胞から産生され る G-CSFによって幼若な顆粒球が骨髄からリク ルートされるためだと思われる.川崎病の治療で用
いられる高濃度 $\mathrm{IgG}$ は，冠動脈の血管内皮細胞に 直接作用して G-CSF などの産生を抑制するらし い. 川崎病血管炎に括いても，組織の細胞と免疫系 とが positive feedbackの機構によって炎症を増悪 させる病態のあることが明らかになったわけで，今 後の治療戦略を考える上で重要な知見と考えられる.

\section{文献}

1）屋代真弓，ほか：川崎病全国調査担当グルー プ: 第 21 回川崎病全国調査成績. 小児科診療 75 (3) : 507-523, 2012.

2）柳川洋，ほか：厚生労働省川崎病研究班： 川崎病診断の手引き改訂 5 版.

(http: //www.kawasaki-disease.org/tebiki / tebiki.html), 2002.

3) Sonobe T, Kiyosawa N, Tsuchiya $\mathrm{K}$ et al. : Prevalence of coronary artery abnormality in incomplete Kawasaki disease. Pediatr Int 49 : 421-426, 2007.

4）日本川崎病学会用語委員会 : 川崎病の用語に 関する規定.

(http://www.jskd.jp/info/pdf/yougo201007. pdf), 2010.

5) Newburger JW, Takahashi M, Gerber MA et al. : Diagnosis, treatment, and long-term management of Kawasaki disease. Circulation 110 : 2747-2771, 2004.

6）日本小児循環器学会学術委員会：川崎病急性 期治療のガイドライン.

(http://www.kawasaki-disease.org/tebiki/pdf 
/guide.pdf), 2003.

7）鮎沢 衛, 原田研介：小児難病の治療 過 去・現在・未来 川崎病 (解説/特集). 小児 科診療 60(1) : 47-55, 1997.

8) Kobayashi $\mathrm{T}$, Inoue $\mathrm{Y}$, Takeuchi $\mathrm{K}$ et al. : Prediction of intravenous immunoglobulin unresponsiveness in patients with Kawasaki disease. Circulation 113 : 2606-2612, 2006.

9) Egami K, Muta H, Ishii M et al. : Prediction of resistance to intravenous immunoglobulin treatment in patients with Kawasaki disease. J Pediatr 149 : 237-240, 2006.

10) Sano $T$, Kurotobi S, Matsuzaki $K$ et al. : Prediction of non-responsiveness to standard high-dose gamma-globulin therapy in patients with acute Kawasaki disease before starting initial treatment. Eur J Pediatr 166 : 131-137, 2007.

11) Kobayashi $\mathrm{T}$ et al. : Efficacy of immunoglobulin plus prednisolone for prevention of coronary artery abnormalities in severe Kawasaki disease (RAISE study) : a randomised, openlabel, blinded-endpoints trial. Lancet 379 (9826) : 1613-1620, 2012.

12) Ogata $\mathrm{S}$, et al. : Corticosteroid pulse combination therapy for refractory Kawasaki disease : a randomized trial. Pediatrics 129(1) : e17-e23, 2011.

13) Sleeper LA, et al. : Evaluation of Kawasaki disease risk-scoring system for intravenous immunoglobulin resistance. $J$ Pediatr 158: 831-835, 2011.

14) Abe J, et al. : Gene-expression profiling of the effect of high-dose intravenous immunoglobulin in patients of Kawasaki Disease. J Immunol $174: 5837-5845,2005$.

15) Abe J, et al. : Elevated granulocyte colonystimulating factor levels predict treatment failure in patients with Kawasaki disease. $J$ Allergy Clin Immunol 122 : 1008-1013, 2008.

16) Theilgaad-Monch K, et al. : The transcriptionalprogram of terminal granulocytic differentiation. Blood 105 : 1785-1796, 2005.

17) Temerinac $S$, et al. : Cloning of PRV-1, a novel member of the uPAR receptor superfamily, which is overexpressed in polycythemia rubra vera. Blood 95 : 2569-2576, 2000.

18) Stroncek DF, et al. : CD177 : A member of the Ly-6 gene superfamily involved with neutrophil proliferation and polycythemia vera. $J$ Trans Med 2 : 8-16, 2004.

19) Hirai $\mathrm{H}$, et al. : $\mathrm{C} / \mathrm{EBPb}$ is required for "emergency" granulopoiesis. Nat Immunol 7 : 732739, 2006.

20) Kohler A, et al. : G-CSF-mediated thrombopoietin release triggers neutrophil motility and mobilization from bone marrow via induction of Cxcr2 ligands. Blood 117 : 4349-4357, 2011.

21) Matsuda A, et al. : Anti-inflammatory effects of high-dose IgG on TNF-a activated human coronary artery endothelial cells. Eur J Immunol 42 : 2121-2131, 2012.

22) Libermann TA, Baltimore, D. : Activation of interleukin-6 gene expression through the NF-kB transcription factor. Mol Cell Biol 10 : 2327-2334, 1990.

23) Suzuki K, et al. : Selective activation of p38 mitogen-activated protein kinase cascade in human neutrophil stimulated bu IL-1 $\beta . \quad J$ Immunol 167 : 5940-5947, 2001.

24) Litvak V, et al, : Function of C/EBP delta in a regulatory circuit that discriminates between transient and persistent TLR4-induced signals. Nat Immunol 10 : 437-443, 2009. 